\title{
EFFECT OF HYPOXIA ON THE EXPRESSION OF GENES THAT ENCODE SOME IGFBP AND CCN PROTEINS IN U87 GLIOMA CELLS DEPENDS ON IRE1 SIGNALING
}

\author{
O. H. MINCHENKO ${ }^{1}$, A. P. KHARKOVA ${ }^{1}$, D. O. MINCHENKO ${ }^{1,2}$, L. L. KARBOVSKYI \\ ${ }^{1}$ Palladin Institute of Biochemistry, National Academy \\ of Sciences of Ukraine, Kyiv; \\ e-mail: ominchenko@yahoo.com; \\ ${ }^{2}$ Bohomolets National Medical University, Kyiv, Ukraine;
}

We have studied hypoxic regulation of the expression of different insulin-like growth factor binding protein genes in U87 glioma cells in relation to inhibition of IRE1 (inositol requiring enzyme-1), a central mediator of endoplasmic reticulum stress, which controls cell proliferation and tumor growth. We have demonstrated that hypoxia leads to up-regulation of the expression of IGFBP6, IGFBP7, IGFBP10/CYR61, WISP1, and WISP2 genes and down-regulation - of IGFBP9/NOV gene at the mRNA level in control glioma cells, being more significant changes for IGFBP10/CYR61 and WISP2 genes. At the same time, inhibition of IRE1 modifies the effect of hypoxia on the expression of all studied genes: eliminates sensitivity to hypoxia the expression of IGFBP7 and IGFBP9/NOV genes, suppresses effect of hypoxia on IGFBP6, IGFBP10/CYR61, and WISP2 genes, and slightly enhances hypoxic regulation of WISP1 gene expression in glioma cells. We have also demonstrated that the expression of all studied genes in glioma cells is regulated by IRE1 signaling enzyme upon normoxic condition, because inhibition of IRE1 significantly up-regulates IGFBP7, IGFBP10/ CYR61, WISP1, and WISP2 genes and down-regulates IGFBP6 and IGFBP9/NOV genes as compared to control glioma cells. The present study demonstrates that hypoxia, which contributes to tumor growth, affects all studied IGFBP and WISP gene expressions and that inhibition of IRE1 preferentially abolishes or suppresses the hypoxic regulation of these gene expressions and thus possibly contributes to slower glioma growth. Moreover, inhibition of IRE1, which correlates with suppression of cell proliferation and glioma growth, is down-regulated expression of pro-proliferative IGFBP genes, attesting to the fact that endoplasmic reticulum stress is a necessary component of malignant tumor growth.

K e y word s: mRNA expression, endoplasmic reticulum stress, IGFBP6, IGFBP7, IGFBP9/NOV, IGFBP10/ CYR61, WISP1, WISP2, IRE1 inhibition, hypoxia, glioma cells.

I nsulin-like growth factor binding proteins (IGFBPs) contain insulin-like growth factor (IGF) binding domain and play an important role in the regulation of numerous metabolic and proliferative processes mainly through interaction with IGF1 and IGF2, their cell surface receptors as well as insulin receptor, alter the half-life of the IGFs, modifying their biological activity. It is well known that insulin-like growth factors and the signal transduction networks play important roles in tumorigenesis and metastasis as well as in metabolic diseases $[1,2]$. IGFBPs participate in endoplasmic reticulum stress, which is an important factor of tumor growth, insulin resistance, and obesity [3-5]. It is interesting to note that there is the cross talk between IGF and insulin receptor signaling pathways at the receptor level or at downstream signaling level. This cross talk significantly changed a variety of cancers as a result of insulin receptor isoform. A formation of hybrid receptor isoforms between receptors for IGF1 and insulin, which are sensitive to the stimulation of all three IGF axis ligands, as well as hybrid receptors of IGF1/insulin receptor with other tyrosine kinase potentiate the transformation of cells, tumorigenesis, and tumor neovascularization [6].

The IGFBPs have different affinity for insulin-like growth factors. They bind and regulate the availability of both insulin-like growth factors and inhibit or stimulate the growth promoting effects of the IGFs through IGF/INS receptors and through other signaling pathways and regulate cell proliferation and survival as well as angiogenesis and cancer 
cell migration. Moreover, both negative and positive correlations between levels of IGF-1/IGF-1-R and clinical outcomes in head and neck cancer have been reported [10]. IGFBPs are now understood to have many actions beyond their endocrine role in IGF transport [6]. IGFBPs also function in the cells and extracellular matrix to regulate cell proliferation and survival and are involved in tumor development, progression and resistance to treatment. Because they interact with many proteins, in addition to their canonical ligands (IGF1 and IGF2), they play an important role in the regulation of various processes including transcription [6, 7]. Thus, IGFBP6 preferentially binds to IGF2 and also has IGF-independent effects, including inhibition of angiogenesis and promotion of cancer cell migration [8]. Moreover, IGFBP6 regulate cell proliferation and apoptosis: down-regulation of this gene expression leads to inhibition of cell proliferation and to increased apoptotic cell death. It is interesting to note that apoptosis can be also regulated through IGF1 receptor; however, there is data that IGFBP6 can also suppress the cellular proliferation [9].

IGFBP7, which is also known as insulin-like growth factor binding protein-related protein 1 (IGFBPRP1), belongs to the IGFBP family whose members have a conserved structural homology. It has a low affinity for IGFs and a high affinity for insulin, suggesting that IGFBP7 may have a biological function distinct from other members of the IGFBP family. IGFBP7 has diverse biological functions, regulating cell proliferation, apoptosis and senescence; it may also play a key role in vascular biology [6]. It elicits its biological effects by both insulin/ IGF-dependent and -independent mechanisms. It has also been shown that IGFBP7 can bind to unoccupied IGF1 receptor, block its activation by insulin-like growth factors and suppress downstream signaling, thereby inhibiting protein synthesis, cell growth, and survival [10]. Increasing evidence suggests that IGFBP7 acts as a tumor suppressor [6].

The CNN family of regulatory protein represents IGFBP9/CCN3/NOV (nephroblastoma overexpressed) and IGFBP10/CCN1/CYR61 (cysteinerich angiogenic inducer 61), which play a role in cell growth regulation and are involved in angiogenesis, inflammation and matrix remodeling [11]. The WNT1 inducible signaling pathway (WISP) proteins WISP1/CCN4 and WISP2/CCN5 are downstream in the WNT1 signaling pathway and are also relevant to malignant transformation, cancer cell surviving, invasion and motility [12-14]. Furthermore, the elevated levels of WISP1/CCN4 and CYR61/CCN1 in primary breast cancers were associated with more advanced features [15].

The endoplasmic reticulum is a dynamic intracellular structure with exquisite sensitivity to alterations in homeostasis and provides stringent quality control systems to ensure that only correctly folded proteins transit to the Golgi [16]. Accumulation of the unfolded or misfolded proteins induces a set of complex intracellular signaling events in the endoplasmic reticulum and restores homeostasis or activates cell death $[17,18]$. Multiple studies have clarified the link between cancer and endoplasmic reticulum stress, which controls different processes, including cell proliferation and surviving, as well as circadian rhythms [19-21]. IRE1 is a central mediator of the unfolded protein response and an important component of tumor growth, and its blockade leads to a suppression of tumor growth through down-regulation of the angiogenesis and proliferation processes [22, 23]. It contributes to the expression profile of many regulatory genes resulting in proliferation, angiogenesis, and apoptosis [3, 17, 24]. IRE1 has two enzymatic activities: kinase, which is responsible for autophosphorylation and some gene expressions, and endoribonuclease, which is responsible for degradation of a specific subset of mRNA and alternative splicing of the XBP1 (X-box binding protein 1) transcription factor mRNA for control of the expression of unfolded protein response-specific genes [25, 26].

The endoplasmic reticulum stress response-signalling pathway is tightly associated with hypoxia and linked to the neovascularization, tumor growth and cell death processes as well as to suppression of insulin receptor signaling through activation of c-Jun N-terminal kinase (JNK) and subsequent serine phosphorylation of IRS1 [27, 28]. The endoplasmic reticulum has an essential position as a signal integrator in the cell and is instrumental in the different phases of tumor progression because the signaling pathways elicited by endoplasmic reticulum stress sensors have connections with metabolic pathways and with other plasma membrane receptor signaling networks $[17,19]$.

Ablation of IRE1 function has been shown to result in a significant anti-proliferative effect in glioma growth through down-regulation of prevalent pro-angiogenic factors and up-regulation of anti-angiogenic genes as well as by modification of hypoxic 
regulation of these genes [24, 29]. However, the executive mechanisms of the exhibited anti-proliferative effects of IRE1 inhibition are not yet known. It is possible that this anti-proliferative effect is also realized through mediation by IFGBPs and its receptors signaling, which are integrated into the unfolded protein response signaling pathways, to regulate cell proliferation and surviving $[8,10,11]$. Possible involvement of insulin-like growth factor binding proteins and CCN family proteins such as IGFBP6, IGFBP7, IGFBP9/NOV, IGFBP10/CYR61, WISP1, and WISP2 was made evidently pertinent through transcriptomic analysis of U87 glioma cells expressing the dominant-negative mutant of IRE1 [23].

The main goal of this study was to investigate the role of expression of genes encoding the insulinlike growth binding proteins with different affinity for IGF proteins (IGFBP6, IGFBP7, IGFBP9/NOV/ CCN3, IGFBP10/CYR61/CCN1, WISP1/CCN4, and WISP2/CCN5) in U87 glioma cell line and its subline with IRE1 loss of function upon hypoxia for evaluation of its possible significance in the control of tumor growth through IRE1 mediated endoplasmic reticulum stress signaling.

\section{Materials and Methods}

Cell Lines and Culture Conditions. The glioma cell line U87 (HTB-14) was obtained from ATCC (USA) and grown in high glucose (4.5 g/l) Dulbecco's modified Eagle's minimum essential medium (DMEM; Gibco, Invitrogen, USA) supplemented with glutamine $(2 \mathrm{mM}), 10 \%$ fetal bovine serum (Equitech-Bio, Inc., USA), penicillin (100 units/ml; Gibco, USA) and streptomycin (0.1 mg/ml; Gibco) at $37^{\circ} \mathrm{C}$ in a $5 \% \mathrm{CO}_{2}$ incubator.

In this work we used sublines of U87 glioma cells, which were described previously [23, 24]. One subline was obtained by selection of stable transfected clones with overexpression of vector pcDNA3.1, which was used for creation of dn-IRE1. This untreated subline of glioma cells (control glioma cells) was used as control 1 in the study of the effect of glucose deprivation on the expression level of different IGFBP and related genes. The second subline was obtained by selection of stable transfected clone with overexpression of IRE1 dominant/negative construct (dn-IRE1) and has suppressed both protein kinase and endoribonuclease activities of this signaling enzyme (clone 1C5) [23]. The expression level of studied genes in these cells was compared with cells, transfected by vector (control 1), but this subline was also used as control 2 for investigation of the effect of glucose deprivation on gene expressions under blockade of both enzymatic activities of IRE1. The efficiency of IRE1 suppression in this glioma cell subline was estimated previously [23, 24] by determining the expression level of the XBP1 alternative splice variant, a key transcription factor in the IRE1 signaling, and the level of the phosphorylated isoform IRE1, using cells treated by tunicamycin $(0.01 \mathrm{mg} / \mathrm{ml}$ during $2 \mathrm{~h})$. The both sublines of glioma cells used in this study are grown with the addition of geneticin (G418), while these cells carried empty vector pcDNA3.1 or dn-IRE1 construct.

For hypoxia culture plates were exposed in a special chamber with $3 \%$ oxygen, $92 \%$ nitrogen, and $5 \%$ carbon dioxide levels for $16 \mathrm{~h}$.

RNA isolation. Total RNA was extracted from glioma cells using Trizol reagent according to manufacturer protocols (Invitrogen, USA) as described previously [24]. The RNA pellets were washed with $75 \%$ ethanol and dissolved in nuclease-free water. For additional purification RNA samples were reprecipitated with 95\% ethanol and re-dissolved again in nuclease-free water.

Reverse transcription and quantitative PCR analysis. QuaniTect Reverse Transcription Kit (QIAGEN, Germany) was used for cDNA synthesis according to manufacturer protocol. The expression level of insulin-like growth factor binding proteins (IGFBP6, IGFBP7, IGFBP9/NOV, and IGFBP10/ CYR61) and WNT1 inducible signaling pathway proteins (WISP1 and WISP2) mRNAs as well as ACTB mRNA were measured in U87 glioma cells by real-time quantitative polymerase chain reaction using Mx 3000P QPCR (Stratagene, USA) and Absolute qPCR SYBRGreen Mix (Thermo Fisher Scientific, ABgene House, UK). Polymerase chain reaction was performed in triplicate using specific primers, which were received from Sigma-Aldrich, USA.

For amplification of IGFBP6 cDNA we used forward (5'-GCTGTTGCAGAGGAGAATCC-3' and reverse (5'-GGTAGAAGCCTCGATGGTCA-3') primers. The nucleotide sequences of these primers correspond to sequences 397-416 and 655-636 of human IGFBP6 cDNA (GenBank accession number NM_002178). The size of amplified fragment is $259 \mathrm{bp}$. The amplification of IGFBP7 cDNA for real time RCR analysis was performed using two oligonucleotide primers: forward - 5'-AGCTGTGAGGTCATCGGAAT- $3^{\prime}$ and reverse $-5^{\prime}$ - TATAGCTCG- 
GCACCTTCACC $-3^{\prime}$. The nucleotide sequences of these primers correspond to sequences 572-591 and 882-863 of human IGFBP7 cDNA (GenBank accession number NM_001553). The size of amplified fragment is $311 \mathrm{bp}$.

The amplification of IGFBP9/NOV/CCN3 cDNA for real time RCR analysis was performed using two oligonucleotide primers: forward $-5^{\prime}-$ GCGAAGAAAGTCTCGTTTGG-3' and reverse 5'-ACACCAGACAGCATGAGCAG-3'. The nucleotide sequences of these primers correspond to sequences 176-195 and 420-401 of human IGFBP9 cDNA (GenBank accession number NM_002514). The size of amplified fragment is $245 \mathrm{bp}$. For amplification of IGFBP10/CYR61/CCN1 cDNA we used forward (5'-CTCCCTGTTTTTGGAATGGA-3' and reverse (5'-TGGTCTTGCTGCATTTCTTG-3') primers. The nucleotide sequences of these primers correspond to sequences 852-871 and 1092-1073 of human IGFBP10 cDNA (GenBank accession number NM_001554). The size of amplified fragment is $241 \mathrm{bp}$.

The amplification of WNT1 inducible signaling pathway protein 1 (WISP1), also known as CCN4, cDNA for real time RCR analysis was performed using two oligonucleotides primers: forward $-5^{\prime}-$ GACTTTACCCCAGCTCCACT-3' and reverse - 5'GTAGTCACAGTAGAGGCCCC- 3 '. The nucleotide sequences of these primers correspond to sequences 203-222 and 415-396 of human WISP1 cDNA (GenBank accession number NM_003882). The size of amplified fragment is $213 \mathrm{bp}$. For amplification of WISP2/CCN5 cDNA we used forward (5'-CTGTATCGGGAAGGGGAGAC $-3^{\prime}$ and reverse $\left(5^{\prime}-\right.$ GGGAAGAGACAAGGCCAGAA-3') primers. The nucleotide sequences of these primers correspond to sequences 463-482 and 709-690 of human WISP2 cDNA (GenBank accession number NM_003881). The size of amplified fragment is $247 \mathrm{bp}$.

The amplification of beta-actin (ACTB) cDNA was performed using forward - 5'-GGACTTCGAGCAAGAGATGG-3' and reverse - 5'-AGCACTGTGTTGGCGTACAG-3' primers. These primer nucleotide sequences correspond to 747-766 and 980-961 of human ACTB cDNA (GenBank accession number NM_001101). The size of amplified fragment is $234 \mathrm{bp}$. The expression of beta-actin mRNA was used as control of analyzed RNA quantity. The primers were received from Sigma-Aldrich (St. Louis, MO, USA).
Quantitative PCR analysis was performed using a special computer program "Differential expression calculator". The values of IGFBP6, IGFBP7, IGFBP9, IGFBP10, WISP1, WISP2 and ACTB gene expressions were normalized to the expression of beta-actin mRNA and represent as percent of control (100\%). All values are expressed as mean \pm SEM from triplicate measurements performed in 4 independent experiments. The amplified DNA fragments were also analyzed on a $2 \%$ agarose gel and that visualized by SYBR* Safe DNA Gel Stain (Life Technologies, Carlsbad, CA, USA).

Statistical analysis. Statistical analysis was performed according to Student's t-test using Excel program as described previously [31]. All values are expressed as mean \pm SEM from triplicate measurements performed in 4 independent experiments.

\section{Results and Discussion}

To determine if hypoxia affects the expression of a subset of genes encoding for different insulinlike growth factor binding proteins through the IRE1 branch of endoplasmic reticulum stress response, we investigated the effect of hypoxic condition on mRNA expression levels of different members of IGFBP and CCN families, which can participate in the regulation of glioma growth through insulinlike growth factor receptors as well as through other signaling pathways and mechanisms.

To investigate a possible role of endoplasmic reticulum stress signaling mediated by signaling enzyme IRE1 in the expression of insulin-like growth factor binding protein gene IGFBP6 and its sensitivity to hypoxia we studied the effect of hypoxic condition on this gene expression in glioma cells with functional IRE1 (control glioma cells) and cells without both enzymatic activities of this signaling enzyme. As shown in Fig. 1, the expression level of IGFBP6 mRNA is significantly up-regulated by hypoxia in both types of glioma cells: $+39 \%$ in control glioma cells in comparison with the control 1 and $+18 \%$ in cells with suppressed function of signaling enzyme IRE1 as compared to control 2. At the same time, the inhibition of IRE1 by dnIRE1 strongly down-regulated the expression level of IGFBP6 mRNA (2.2-fold) in glioma cells in comparison with the control cells (Fig. 1).

We next tested the sensitivity of IGFBP7 gene expressions to hypoxia and whether IRE1 also participates in the hypoxic regulation of this gene. We 


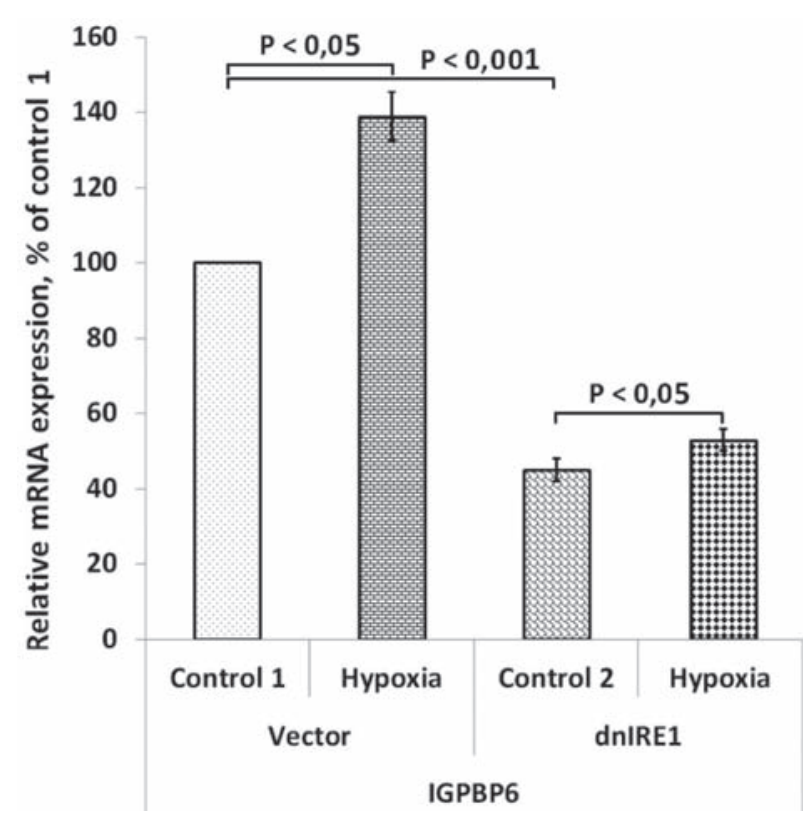

Fig. 1. Effect of hypoxia on the expression level of insulin-like growth factor binding protein 6 (IGFBP6) mRNA in control U87 glioma cells (Vector) and cells with a blockade of the IRE1 by dn-IRE1 (dn-IRE1) measured by qPCR. Values of IGFBP6 mRNA expressions were normalized to $\beta$-actin $m R N A$ level and represented as percent of control 1 (100\%); $n=4$

have found that the expression of IGFBP7 gene is also up-regulated by hypoxia in control glioma cells $(+17 \%)$, but cells without IRE1 signaling enzyme function are resistant to hypoxia in comparison with the corresponding control (control 2) (Fig. 2). At the same time, the inhibition of IRE1 in glioma cells strongly up-regulated the expression of IGFBP7 gene upon normoxic condition as compared to control 1 (2.9-fold; Fig. 2).

Next we investigated the cysteine-rich regulatory proteins IGFBP9/NOV/CCN3 and IGFBP10/ CYR61/CCN1, which have insulin-like growth factor binding domain and are members of CCN family proteins, associate with the extracellular matrix and play an important role in cancer development by regulation of angiogenesis, cell migration and proliferation. We tested how hypoxia affects these insulin-like growth factor binding protein genes and how IRE1 inhibition modifies the effect of hypoxia on the expression of IGFBP9/NOV and IGFBP10/ CYR61 genes. In Fig. 3 and 4 is shown the expression of IGFBP9/NOV and IGFBP10/CYR61 genes, which are sensitive to hypoxia, but their expression changed in diverse ways. Thus, hypoxia decreases

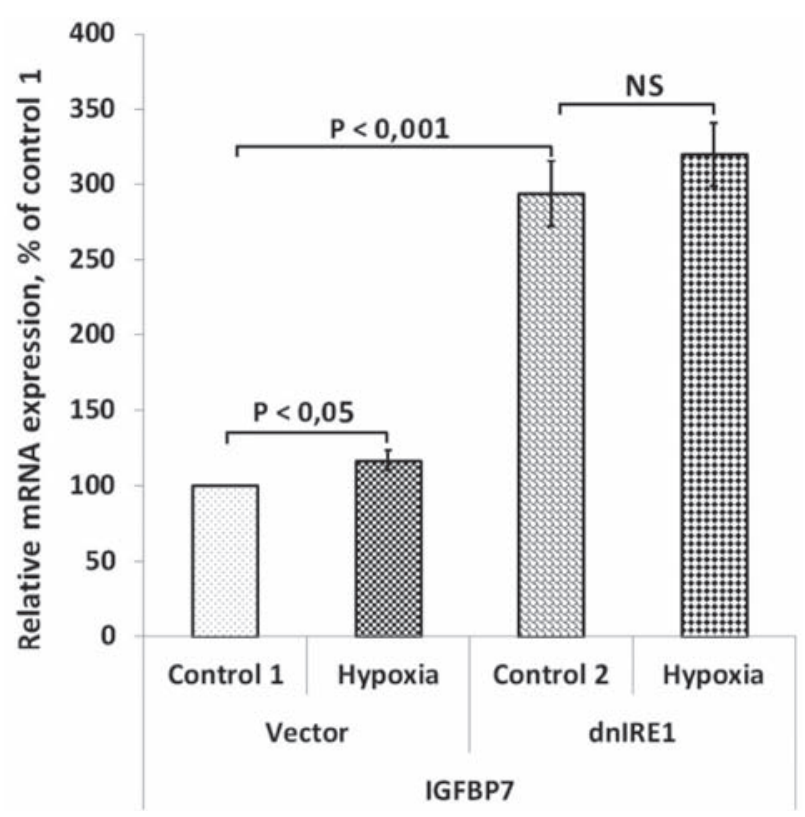

Fig. 2. Effect of hypoxia on the expression level of insulin-like growth factor binding protein 7 (IGFBP7) mRNA in control U87 glioma cells (Vector) and cells with a blockade of the IRE1 by dn-IRE1 (dn-IRE1) measured by qPCR. Values of IGFBP7 mRNA expressions were normalized to $\beta$-actin $m R N A$ level and represented as percent of control 1 (100\%); $n=4$

the expression of IGFBP9/NOV gene (-39\%) and induces IGFBP10/CYR61 gene expression (+67\%). However, the inhibition of IRE1 eliminates the effect of hypoxia on IGFBP9/NOV gene expression in glioma cells, but expression of IGFBP10/CYR61 gene is also increased (+44\%) in these glioma cells (Fig. 3 and 4). Thereafter, we studied the effect of inhibition of IRE1 enzyme function by dn-IRE1 on the expression of IGFBP9/NOV gene in glioma cells upon normoxic condition. As shown in Fig. 3, the expression of IGFBP9/NOV gene is strongly down-regulated (4.8-fold) by inhibition of IRE1 signaling enzyme. At the same time, the expression of IGFBP10/CYR61 gene significantly increased (1.5-fold) in these glioma cells in comparison with control glioma cells. Thus, the inhibition of IRE1 signaling enzyme function affects the expression level of IGFBP9/NOV and IGFBP10/CYR61 mRNAs in gene-specific manner.

We next studied the effect of hypoxia on the expression of WNT1 inducible signaling pathway proteins (WISP1 and WISP2), which have IGF binding domain and are members of CCN family proteins as well as IGFBP9/NOV/CCN3 and IGFBP10/CYR61/ CCN1. As shown in Fig. 5, the expression of WISP1/ 


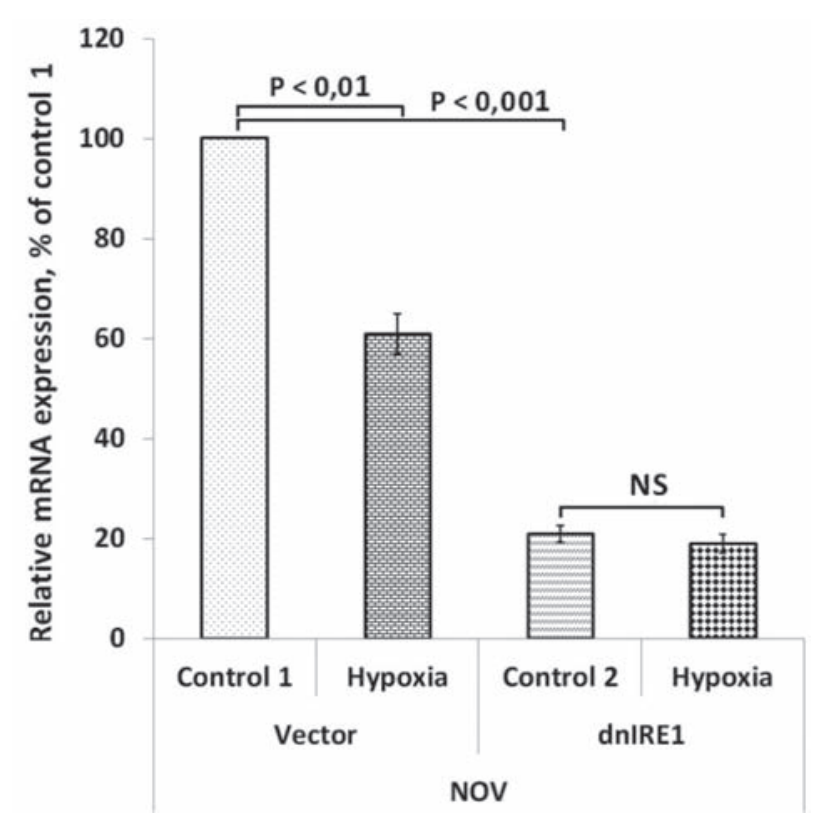

Fig. 3. Effect of hypoxia on the expression level of insulin-like growth factor binding protein 9 (IGFBP9), also known as NOV (nephroblastoma overexpressed) and CCN3 (CCN family member 3), mRNA in control U87 glioma cells (Vector) and cells with a blockade of the IRE1 by dn-IRE1 (dn-IRE1) measured by qPCR. Values of IGFBP9 mRNA expressions were normalized to $\beta$-actin $m R N A$ level and represented as percent of control 1 (100\%); $n=4$

CCN4 gene at mRNA level is up-regulated by hypoxia both in cells with native IRE1 and cells with inhibited function of IRE1 signaling enzyme: $+45 \%$ in control glioma cells and $+68 \%$ in cells with a deficiency of IRE1 enzyme function. We have also shown that the inhibition of IRE1 signaling enzyme leads to strong up-regulation of WISP1/CCN4 gene expression (8.4-fold) in glioma cells upon normoxic condition (Fig. 5).

Significant up-regulation was also shown for the expression of WISP2/CCN5 gene upon hypoxia in both types of glioma cells: 2.6-fold in control glioma cells and 1.8-fold in cells without IRE1 enzyme function as compared to corresponding controls (Fig. 6). Moreover, the inhibition of IRE1 is strongly up-regulated expression of WISP2/CCN5 gene at mRNA level in glioma cells upon normoxic condition (3.6-fold) as compared to control 1.

Additionally, we analyzed the effect of hypoxic condition on the expression level of IGFBP6, IGFBP10/CYR61/CCN1, WISP1/CCN4, and WISP2/

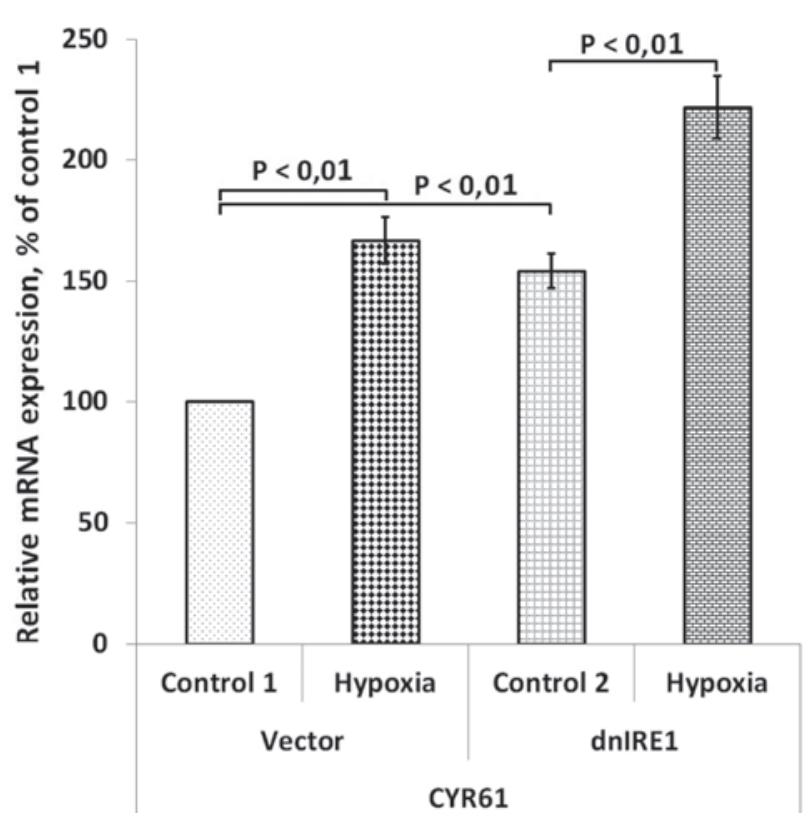

Fig. 4. Effect of hypoxia on the expression of insulinlike growth factor binding protein 10 (IGFBP10), also known as CYR61 (cysteine-rich angiogenic inducer 61) and CCN1 (CCN family member 1), mRNA in control U87 glioma cells (Vector) and cells with a blockade of the IRE1 by dn-IRE1 (dn-IRE1) measured by qPCR. The values of IGFBP10 mRNA expressions were normalized to $\beta$-actin $m R N A$ level and represented as percent of control 1 (100\%); $n=4$

CCN5 mRNA in glioma cells with intact and inhibited IRE1 enzyme function in conditions when both controls (control 1 and control 2) are established as $100 \%$ to more precisely clarify the difference in the sensitivity of these gene expressions to hypoxia in respect to inhibition of IRE1. As shown in Fig. 7, there are statistically significant differences in the expression levels of IGFBP6, IGFBP10/CYR61, WISP1, and WISP2 mRNA in control glioma cells and cells without IRE1 function exposure upon hypoxia: 2.17-fold for IGFBP6, 1.52-fold for IGFBP10/ CYR61, 1.51-fold for WISP1, and 2.02-fold for WISP2.

In this work we studied the expression of genes which encoded different insulin-like growth factor binding proteins in glioma cells with inhibition of IRE1 signaling enzyme function upon hypoxia for evaluation of possible significance of these genes in the control of glioma growth through endoplasmic reticulum stress signaling mediated by IRE1 and hypoxia. Investigation of the expression of different 


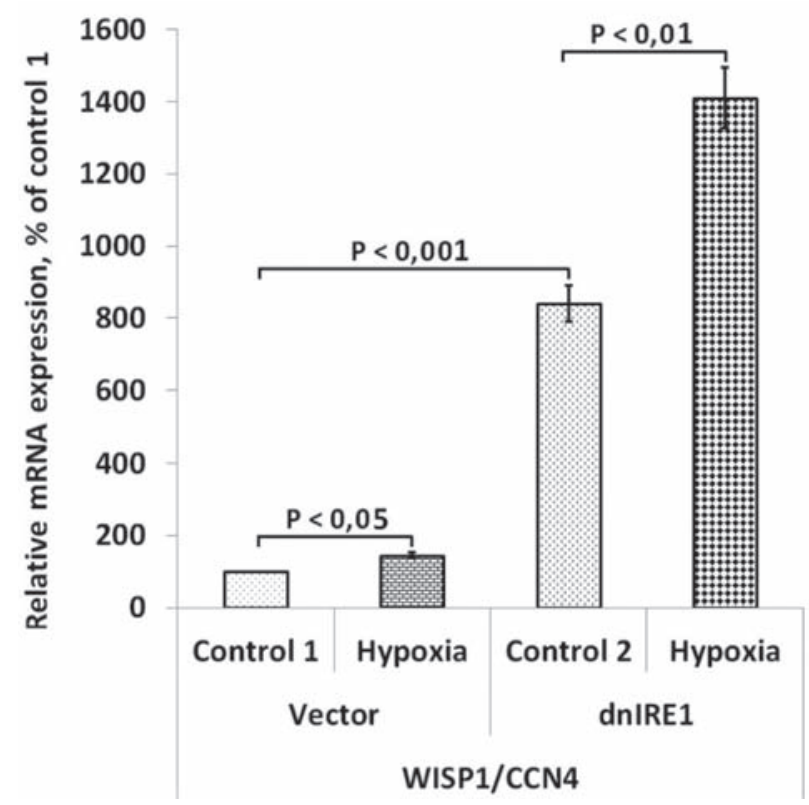

Fig. 5. Effect of hypoxia on the expression of WNT1 inducible signaling pathway protein 1 (WISP1), also known as CCN4 (CCN family member 4), mRNA in control U87 glioma cells (Vector) and cells with a blockade of the IRE1 by dn-IRE1 (dn-IRE1) measured by qPCR. Values of WISP1 mRNA expressions were normalized to $\beta$-actin $m R N A$ level and represented as percent of control 1 (100\%); $n=4$

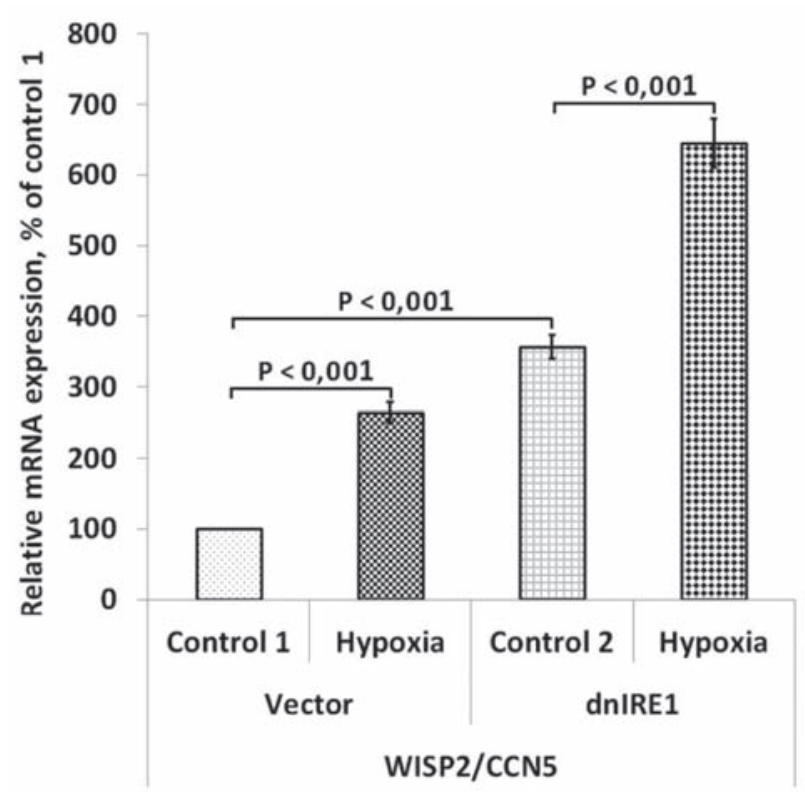

Fig. 6. Effect of hypoxia on the expression of WNT1 inducible signaling pathway protein 2 (WISP2), also known as CCN5 (CCN family member 5), mRNA in control U87 glioma cells (Vector) and cells with a blockade of the IRE1 by dn-IRE1 (dn-IRE1) measured by qPCR. Values of WISP 2 mRNA expressions were normalized to $\beta$-actin $m R N A$ level and represented as percent of control 1 (100\%); $n=4$

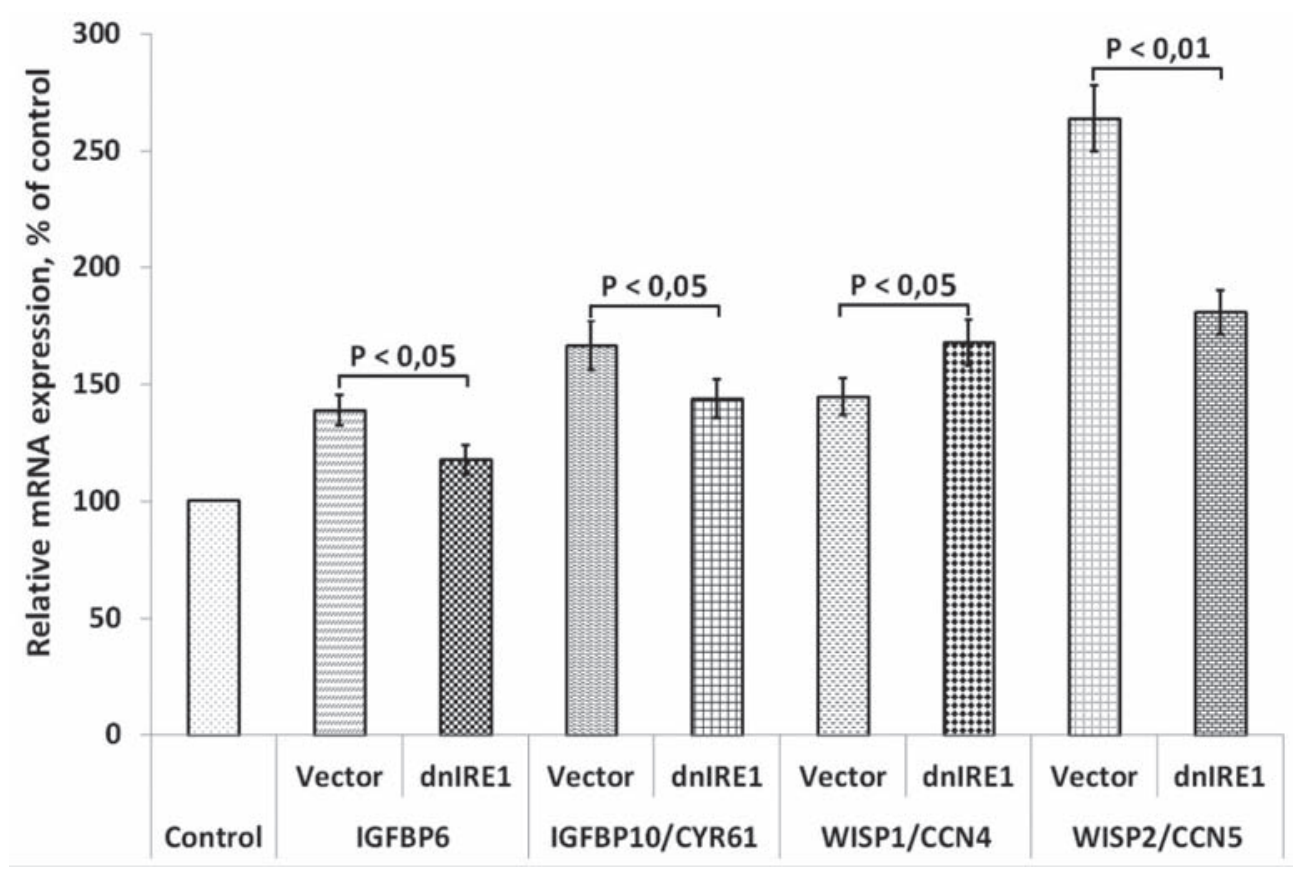

Fig. 7. Inhibition of IREI modifies the effect of hypoxia on the expression of IGFBP7, IGFBPI0/CYR61, WISPI, and WISP2 mRNA in glioma cells (by qPCR). These mRNA expression values were normalized to $\beta$-actin $m R N A$ expression and represented as percent of corresponding control (both controls are taken as 100\%); mean \pm SEM; $n=4$ 
genes of IGFBP and CCN families in glioma cells upon hypoxia in respect of inhibition of IRE1 signaling is very important for understanding the malignant tumor growth mechanisms, because hypoxia as well as nutrient deprivation plays essential role in the control of tumor progression [27, 32]. Thus, our results are consistent with numerous data [22, 30] that hypoxia is associated with malignant progression through the endoplasmic reticulum unfolded protein response, but mechanism how malignant cells cope with potentially lethal metabolic stress induced by hypoxia remains poorly understood.

The growing tumor requires the endoplasmic reticulum stress as well as hypoxia and nutrient deprivation, which initiate the endoplasmic reticulum stress for own neovascularization and growth, for apoptosis inhibition [23, 30]. Cell proliferation is strongly dependent upon hypoxia and glycolysis because there is the molecular connection between cell cycle progression and the provision of substrates essential for this purpose [30, 33]. The endoplasmic reticulum has an important position as a signal integrator in both normal and malignant cells because the endoplasmic reticulum stress signaling pathways have connections with other plasma membrane receptor signaling networks and with numerous metabolic pathways [19, 30]. It has been known that the complete blockade of the activity of IRE1 signaling enzyme in glioma cells had anti-tumor effects $[24,29]$.

In this study we have also demonstrated that the expression of all studied genes in glioma cells is regulated by IRE1 signaling enzyme upon normoxic condition, because inhibition of IRE1 significantly up-regulates IGFBP7, IGFBP10/CYR61, WISP1 and WISP2 genes and down-regulates IGFBP6 and IG$F B P 9 / N O V$ genes as compared to control glioma cells and that these genes participate in IRE1 mediated network of unfolded protein response. It is possible that decreased expression of IGFBP6 and IGFBP9/NOV genes in glioma cells without both enzymatic activities of IRE1 contributes to the suppression of glioma growth from cells with IRE1 knockdown [23, 24] because our results conform to data that IGFBP6 and IGFBP9/NOV have mainly pro-proliferative functions through interaction with different proteins and signaling pathways and are overexpressed in various malignant tumors $[6,11]$.

The insulin-like growth factor binding proteins bind and regulate the availability of both IGFs with different affinity and inhibit or stimulate the growth promoting effects of the IGFs through IGF/ insulin receptors and through many other signaling pathways and regulate cell proliferation and survival as well as angiogenesis and cancer cell migration $[6,11]$. In this study we have shown that inhibition of IRE1 signaling, which is a central mediator of the unfolded protein response and an important component of malignant tumor growth, strongly upregulated the expression level of IGFBP7 gene in glioma cells and that this induction of IGFBP7 possibly contributes to suppression of IRE1 knockdown cell proliferation, because this protein acts as a tumor suppressor [6]. Moreover, the effect of this protein on cell proliferation, apoptosis and senescence is realized through both insulin/IGF-dependent and -independent mechanisms [6].

We also observed significant induction of $I G$ FBP10/CYR61/CCN1, WISP1/CCN4 and WISP2/ CCN5 gene expressions in glioma cells by inhibition of IRE1 signaling enzyme, which supports the IRE1-mediated mechanisms of the expression of both these genes. Furthermore, up-regulation of the expression of these multifunctional proteins in glioma cells after inhibition of IRE1 can also contribute to the suppression of these glioma cells proliferation, because there is data that elevated expression of WISP-1 and CYR61 in primary breast cancers associated with more advanced features [14]. It is possible that IGFBP10/CYR61/CCN1 can suppress hepatocarcinogenesis by inhibiting compensatory proliferation [34], although its role in tumor growth is not well established yet. At the same time, an increased level of CYR61/CCN1 as well as a decreased level of NOV/CCN3 possibly has relation to increased metastasis of glioma cells without IRE1 function [40], because CYR61/CCN1 is responsible for induction of the tumor epithelial-mesenchymal transition, invasion, and metastasis as well as inhibition of NOV levels promotes the invasive phenotype of metastatic cancer cells [35]. Furthermore, elevated levels of WISP1 and CYR61 in primary breast cancers associated with more advanced features [14]. WISP2 is a transcriptional repressor of genes associated with the epithelial-mesenchymal transition; it is undetectable in more aggressive breast cancer cells [15]. Consequently, up-regulation of WISP1 and WISP2 gene expression in glioma cells after inhibition of IRE1 can also contribute to the suppression of this proliferation of glioma cells.

Thus, the changes observed in the most above studied insulin-like growth factor binding proteins 
gene expressions correlate well with slower cell proliferation in cells harboring dn-IRE1, attesting to the fact that endoplasmic reticulum stress is a necessary component of malignant tumor growth, cell survival and metastasis. Moreover, our results demonstrate that hypoxia, which contributes to tumor growth, affects all studied insulin-like growth factor binding protein and WNT1 inducible signaling pathway protein gene expressions and that inhibition of IRE1 preferentially abolishes or suppresses the hypoxic regulation of these gene expressions and thus possibly contributes to slower glioma growth. However, the detailed molecular mechanisms of IRE1-mediated hypoxic regulation of these genes, which have a pivotal role in the control of cell proliferation as well as metastasis, are complex and warrants further investigation.

\section{ЕФЕКТ ГІПОКСІЇ НА ЕКСПРЕСІЮ ГЕНІВ, ЩО КОДУЮТЬ ДЕЯКІ IGFВР ТА ССN ПРОТЁ̈НИ, В КЛІТИНАХ ГЛІОМИ ЛІНІЇ U87 ЗАЛЕЖИТЬ ВІД IRE1 СИГНАЛЮВАННЯ}

\section{О. Г. Мінченко ${ }^{1}$, А. П. Харькова ${ }^{1}$, Д. О. Мінченко ${ }^{1,2}$, Л. Л. Карбовський}

${ }^{1}$ Інститут біохімії ім. О. В. Палладіна НАН України, Київ; e-mail: ominchenko@yahoo.com; ${ }^{2}$ Національний медичний університет ім. О. О. Богомольця, Київ, Україна

Ми вивчали регуляцію гіпоксією експресії різних генів протеїнів, що зв'язуються iз подібними до інсуліну факторами росту, у клітинах гліоми лінії U87 у зв'язку 3 пригніченням IRE1 (залежного від інозитолу ензиму 1) - центрального медіатора стресу ендоплазматичного ретикулума, який контролює проліферацію клітин та ріст гліоми. Встановлено, що за гіпоксії спостерігається посилення експресії генів IGFBP6, IGFBP7, IGFBP10/CYR61, WISP1 та WISP2 і зниження гена - IGFBP9/NOV на рівні мРНК у контрольних клітинах гліоми, причому вираженіші зміни виявлено для генів IGFBP10/CYR61 та WISP2. Водночас, пригнічення IRE1 модифікує ефект гіпоксії на експресію всіх досліджених генів: ліквідує чутливість до гіпоксії експресії генів IGFBP7 та IGFBP9/ NOV, знижує ефект гіпоксії на IGFBP6, IGFBP10/ CYR61 та WISP2 і злегка посилює регуляцію гіпоксією експресію гена WISP1 у клітинах гліоми. Показано, що експресія всіх досліджених генів у клітинах гліоми регулюється сигнальним ензимом IRE1 за умов нормоксії, оскільки пригнічення IRE1 істотно посилює експресію генів IGFBP7, IGFBP10/CYR61, WISP1 та WISP2 і знижує експресію генів IGFBP6 та IGFBP9/ NOV порівняно 3 контрольними клітинами гліоми. Результати цієї роботи продемонстрували, що гіпоксія сприяє росту пухлин, порушує експресію всіх досліджених генів груп IGFBP та WISP і що пригнічення IRE1 переважно знімає чи знижує регуляцію гіпоксією експресії цих генів $\mathrm{i}$, таким чином, можливо, робить внесок у зниження росту гліоми. Більше того, пригнічення IRE1, що корелює зі зниженням інтенсивності проліферації клітин та росту гліоми, знижує експресію про-проліферативних генів IGFBP6 та IGFBP9/NOV, підтверджуючи той факт, що стрес ендоплазматичного ретикулума $€$ необхідним компонентом росту злоякісних пухлин.

Ключов і слова: експресія мРНК, стрес ендоплазматичного ретикулума, IGFBP6, IGFBP7, IGFBP9/NOV, IGFBP10/CYR61, WISP1, WISP2, пригнічення IRE1, гіпоксія, клітини гліоми.

\section{ЭФФЕКТ ГИПОКСИИ НА ЭКСПРЕССИЮ ГЕНОВ, КОДИРУЮЩИХ НЕКОТОРЫЕ IGFВР И ССN ПРОТЕИНЫ, В КЛЕТКАХ ГЛИОМЫ ЛИНИИ Ч87 ЗАВИСИТ ОТ IRE1 СИГНАЛИНГА}

\author{
О. Г. Минченко, А. П. Харькова ${ }^{1}$, \\ Д. О. Минченко ${ }^{1,2}$, Л. Л. Карбовский \\ ${ }^{1}$ Институт биохимии им. А. В. Палладина \\ НАН Украины, Киев; \\ e-mail: ominchenko@yahoo.com; \\ ${ }^{2}$ Национальный медицинский университет \\ им. А. А. Богомольца, Киев, Украина
}

Мы изучали регуляцию гипоксией экспрессии генов протеинов, которые связываются с подобными инсулину факторами роста, в клетках глиомы линии U87 в связи с угнетением IRE1 (зависимого от инозитола энзима 1) - центрального медиатора стресса эндоплазматического ретикулума, который контролирует пролиферацию клеток и рост глиомы. Установлено, что при гипоксии отмечается усиление экспрессии генов IGFBP6, IGFBP7, IGFBP10/CYR61, WISP1 и 
WISP2 и снижение гена - IGFBP9/NOV на уровне мРНК в контрольных клетках глиомы, причем более выраженные изменения выявлены для генов IGFBP10/CYR61 и WISP2. В то же время, угнетение IRE1 модифицирует эффект гипоксии на экспрессию всех исследованных генов: ликвидирует чувствительность к гипоксии экспрессии генов IGFBP7 и IGFBP9/NOV, снижает эффект гипоксии на IGFBP6, IGFBP10/CYR61 и WISP2, слегка усиливает регуляцию гипоксией экспрессии гена WISP1 в клетках глиомы. Показано, что экспрессия всех исследованных генов в клетках глиомы регулируется сигнальным энзимом IRE1 при нормоксии, поскольку угнетение IRE1 существенно усиливает экспрессию генов IGFBP7, IGFBP10/CYR61, WISP1 и WISP2 и снижает экспрессию генов IGFBP6 и IGFBP9/NOV по сравнению с контрольными клетками глиомы. Результаты этой работы продемонстрировали, что гипоксия содействует росту опухоли, нарушает экспрессию всех исследованных генов групп IGFBP и WISP и что угнетение IRE1 преимущественно снимает или снижает регуляцию гипоксией экспрессии этих генов и, таким образом, возможно, вносит вклад в снижение роста глиомы. Более того, угнетение IRE1, коррелирующее со снижением интенсивности пролиферации клеток и роста глиомы, снижает экспрессию про-пролиферативных генов IGFBP6 и IGFBP9/NOV, подтверждая тот факт, что стресс эндоплазматического ретикулума является необходимым компонентом роста злокачественных опухолей.

Ключевы е слова: экспрессия мРНК, стресс эндоплазматического ретикулума, IGFBP6, IGFBP7, IGFBP9/NOV, IGFBP10/CYR61, WISP1, WISP2, угнетение IRE1, гипоксия, клетки глиомы.

\section{References}

1. Pollak M. Insulin and insulin-like growth factor signaling in neoplasia. Nat. Rev. Cancer. 2008; 8(12): 915-928.

2. Ozcan U., Cao Q., Yilmaz E., Lee A. H., Iwakoshi N. N., Ozdelen E., Tuncman G., Görgün C., Glimcher L. H., Hotamisligil G. S. Endoplasmic reticulum stress links obesity, insulin action, and type 2 diabetes. Science. 2004; 306(5695): 457-461.

3. Kuijjer M. L., Peterse E. F., van den Akker B. E., Briaire-de Bruijn I. H., Serra M., Meza-
Zepeda L. A., Myklebost O., Hassan A. B., Hogendoorn P. C., Cleton-Jansen A. M. IR/ IGF1R signaling as potential target for treatment of high-grade osteosarcoma. BMC Cancer. 2013; 13: 245.

4. Lee J., Ozcan U. Unfolded protein response signaling and metabolic diseases. J. Biol. Chem. 2014; 289(3): 1203-1211.

5. Minchenko D. O., Kharkova A. P., Tsymbal D. O., Karbovskyi L. L., Minchenko O. H. Expression of insulin-like growth factor binding protein genes and its hypoxic regulation in U87 glioma cells depends on ERN1 mediated signaling pathway of endoplasmic reticulum stress. Endocr. Regul. 2015; 49(2): 73-83.

6. Baxter R. C. IGF binding proteins in cancer: mechanistic and clinical insights. Nat. Rev. Cancer. 2014; 14(5): 329-341.

7. Ellis B. C., Graham L. D., Molloy P. L. CRNDE, a long non-coding RNA responsive to insulin/ IGF signaling, regulates genes involved in central metabolism. Biochim. Biophys. Acta. 2014; 1843(2): 372-386.

8. Bach L.A., Fu P., Yang Z. Insulin-like growth factor-binding protein-6 and cancer. Clin. Sci. (Lond). 2013; 124(4): 215-229.

9. Pan Y., Liang H., Liu H., Li D., Chen X., Li L., Zhang C. Y., Zen K. Platelet-secreted microRNA-223 promotes endothelial cell apoptosis induced by advanced glycation end products via targeting the insulin-like growth factor 1 receptor. J. Immunol. 2014; 192(1): 437446.

10. Evdokimova V., Tognon C. E., Benatar T., Yang W., Krutikov K., Pollak M., Sorensen P. H., Seth A. IGFBP7 binds to the IGF-1 receptor and blocks its activation by insulin-like growth factors. Sci. Signal. 2012; 5(255): ra92.

11. Wagener J., Yang W., Kazuschke K., Winterhager E., Gellhaus A. CCN3 regulates proliferation and migration properties in Jeg3 trophoblast cells via ERK1/2, Akt and Notch signalling. Mol. Hum. Reprod. 2013; 19(4): 237249.

12. Schlegelmilch K., Keller A., Zehe V., Hondke S., Schilling T., Jakob F., Klein-Hitpass L., Schütze N. WISP 1 is an important survival factor in human mesenchymal stromal cells. Gene. 2014; 551(2): 243-254.

13. Gurbuz I., Chiquet-Ehrismann R. CCN4/WISP1 (WNT1 inducible signaling pathway protein 1): 
a focus on its role in cancer. Int. J. Biochem. Cell Biol. 2015;62:142-146.

14. Xie D., Nakachi K., Wang H., Elashoff R., Koeffler H. P. Elevated levels of connective tissue growth factor, WISP-1, and CYR61 in primary breast cancers associated with more advanced features. Cancer Res. 2001; 61(24): 8917-8923.

15. Wang S., Kaufman R. J. The impact of the unfolded protein response on human disease. J. Cell Biol. 2012;197(7):857-867.

16. Yadav R. K., Chae S. W., Kim H. R., Chae H. J. Endoplasmic reticulum stress and cancer. J. Cancer Prev. 2014; 19(2): 75-88.

17. Manié S. N., Lebeau J., Chevet E. Cellular mechanisms of endoplasmic reticulum stress signaling in health and disease. 3. Orchestrating the unfolded protein response in oncogenesis: an update. Am. J. Physiol. Cell Physiol. 2014; 307(10): C901-C907.

18. Clarke H. J., Chambers J. E., Liniker E., Marciniak S. J. Endoplasmic reticulum stress in malignancy. Cancer Cell. 2014; 25(5): 563-573.

19. Bravo R., Parra V., Gatica D., Rodriguez A. E., Torrealba N., Paredes F., Wang Z. V., Zorzano A., Hill J. A., Jaimovich E., Quest A. F., Lavandero S. Endoplasmic reticulum and the unfolded protein response: dynamics and metabolic integration. Int. Rev. Cell. Mol. Biol. 2013; 301: 215-290.

20. Pluquet O., Dejeans N., Chevet E. Watching the clock: endoplasmic reticulum-mediated control of circadian rhythms in cancer. Ann. Med. 2014; 46(4): 233-243.

21. Hetz C., Chevet E., Harding H. P. Targeting the unfolded protein response in disease. Nat. Rev. Drug Discov. 2013; 12(9): 703-719.

22. Drogat B., Auguste P., Nguyen D. T., Bouchecareilh M., Pineau R., Nalbantoglu J., Kaufman R. J., Chevet E., Bikfalvi A., Moenner M. IRE1 signaling is essential for ischemia-induced vascular endothelial growth factor-A expression and contributes to angiogenesis and tumor growth in vivo. Cancer Res. 2007; 67(14): 6700-6707.

23. Auf G., Jabouille A., Guérit S., Pineau R., Delugin M., Bouchecareilh M., Magnin N., Favereaux A., Maitre M., Gaiser T., von Deimling A., Czabanka M., Vajkoczy P., Chevet E., Bikfalvi A., Moenner M. Inositolrequiring enzyme 1alpha is a key regulator of angiogenesis and invasion in malignant glioma.
Proc. Natl. Acad. Sci. USA. 20101; 107(35): 15553-15558.

24. Auf G., Jabouille A., Delugin M., Guérit S., Pineau R., North S., Platonova N., Maitre M., Favereaux A., Vajkoczy P., Seno M., Bikfalvi A., Minchenko D., Minchenko O., Moenner M. High epiregulin expression in human U87 glioma cells relies on IRE1 alpha and promotes autocrine growth through EGF receptor. BMC Cancer. 2013; 13: 597.

25. Acosta-Alvear D., Zhou Y., Blais A.,Tsikitis M., Lents N. H., Arias C., Lennon C. J., Kluger Y., Dynlacht D. D. XBP1 controls diverse cell typeand condition-specific transcriptional regulatory networks. Mol. Cell. 2007; 27: 53-66.

26. Pluquet O., Dejeans N., Bouchecareilh M., Lhomond S., Pineau R., Higa A., Delugin M., Combe C., Loriot S., Cubel G., Dugot-Senant N., Vital A., Loiseau H., Gosline S. J., Taouji S., Hallett M., Sarkaria J. N., Anderson K., Wu W., Rodriguez F. J., Rosenbaum J., Saltel F., Fernandez-Zapico M. E., Chevet E. Posttranscriptional regulation of PER1 underlies the oncogenic function of IRE $\alpha$. Cancer Res. 2013; 73(15): 4732-4743.

27. Chesney J., Clark J., Klarer A. C., ImbertFernandez Y., Lane A. N,, Telang S. Fructose2,6-bisphosphate synthesis by 6-phosphofructo2-kinase/fructose-2,6-bisphosphatase 4 (PFKFB4) is required for the glycolytic response to hypoxia and tumor growth. Oncotarget. 2014; 5: 6670-6686.

28. Lenihan C. R, Taylor C. T. The impact of hypoxia on cell death pathways. Biochem. Soc. Trans. 2013; 41(2): 657-663.

29. Minchenko O. H., Tsymbal D. O., Moenner M., Minchenko D. O., Kovalevska O. V., Lypova N. M. Inhibition of the endoribonuclease of ERN1 signaling enzyme affects the expression of proliferation-related genes in U87 glioma cells. Endoplasm. Reticul. Stress Dis. 2015; 2(1): 18-29.

30. Minchenko O. H., Kharkova A. P., Bakalets T. V., Kryvdiuk I. V. Endoplasmic reticulum stress, its sensor and signaling systems and the role in the regulation of gene expressions in malignant tumor growth and hypoxia. Ukr. Biokhim. Zhurn. 2013; 85(5): 5-16.

31. Bochkov V. N., Philippova M., Oskolkova O., Kadl A., Furnkranz A., Karabeg E., Breuss J., Minchenko O. H., Mechtcheriakova D., Hohen- 
sinner P., Rychli K., Wojta J., Resink T., Binder B. R., Leitinger N. Oxidized phospholipids stimulate angiogenesis via induction of VEGF, IL-8, COX-2 and ADAMTS-1 metalloprotease, implicating a novel role for lipid oxidation in progression and destabilization of atherosclerotic lesions. Circ. Res. 2006; 99(8): 900-908.

32. Colombo S. L., Palacios-Callender M., Frakich N., Carcamo S., Kovacs I., Tudzarova S., Moncada S. Molecular basis for the differential use of glucose and glutamine in cell proliferation as revealed by synchronized HeLa cells. Proc. Natl. Acad. Sci. USA. 2011; 108(52): 2106921074.
33. Yalcin A., Clem B. F., Imbert-Fernandez Y., Ozcan S. C., Peker S., O’Neal J., Klarer A. C., Clem A. L., Telang S., Chesney J. 6-Phosphofructo-2-kinase (PFKFB3) promotes cell cycle progress ion and suppresses apoptosis via Cdk1mediated phosphorylation of p27. Cell Death Dis. 2014; 5(7): e1337.

34. Cheng G., Zhang H., Zhang L., Zhang J. Cyr61 promotes growth of glioblastoma in vitro and in vivo. Tumour Biol. 2015; 36(4): 2869-2873.

35. Hou C. H., Lin F. L., Hou S. M., Liu J. F. Cyr61 promotes epithelial-mesenchymal transition and tumor metastasis of osteosarcoma by Raf-1/ MEK/ERK/Elk-1/TWIST-1 signaling pathway. Mol. Cancer. 2014; 13: 236.

Received 13.08.2015 